\title{
HPLC-DAD-ESI/MS MONITORING OF STILBENES CONTENT IN VRANAC RED WINES PRODUCED WITH TRADITIONAL AND MODERN FERMENTATION METHODS
}

\author{
Danijela Raičević ${ }^{1}$, Tatjana Popović ${ }^{1}$, Violeta Ivanova-Petropulos²*, \\ Jasmina Petreska Stanoeva ${ }^{3}$, Vesna Maraš ${ }^{4}$ \\ ${ }^{1}$ Biotechical Faculty, University of Montenegro, Mihaila Lalića 1, Podgorica, Montenegro \\ ${ }^{2}$ Faculty of Agriculture, University "Goce Delčev", Štip, Krste Misirkov 10-A, \\ 2000 Štip, Republic of N. Macedonia \\ ${ }^{3}$ Institute of Chemistry, Faculty of Natural Sciences and Mathematics, \\ Ss. Cyril and Methodius University, Arhimedova 5, Skopje, Republic of N. Macedonia \\ ${ }^{4}$ 13. Jul - Plantaže, Put Radomira Ivanovića 2, Podgorica, Montenegro \\ violeta.ivanova@ugd.edu.mk
}

\begin{abstract}
Quantification of stilbenes was performed on Vranac wines (vintage 2008 and 2009) produced by traditional and modern fermentation methods, applying different enological additions (enzyme, oak chips and grape tannins). Stilbenes, trans-resveratrol and trans-resveratrol-3-glucoside were determined using the high-performance liquid chromatography (HPLC) coupled to a diode array detector (DAD) and electrospray mass spectrometer (ESI-MS) technique. Trans-resveratrol ranged from 0.09 to $3.30 \mathrm{mg} / \mathrm{l}$ and trans-resveratrol-3-glucoside from 1.13 to $2.60 \mathrm{mg} / \mathrm{l}$. The vintage, fermentation tanks and enological additions influenced the content of stilbenes. Wines from vintage 2008 presented higher amount of stilbenes (on average: $1.89 \mathrm{mg} / \mathrm{l}$ ) compared to the wines from 2009 (on average: $1.59 \mathrm{mg} / \mathrm{l}$ ), probably because of the difference in the temperature and humidity in both years. Application of modern fermentation tanks (Sifa and Ganimede) followed by additions of enzyme, oak chips and grape tannins resulted in a higher amount of stilbenes. Principal Component Analysis (PCA) presented grouping of wines according to the applied fermentation method.
\end{abstract}

Keywords: stilbenes; fermentation; enological additions; Vranac; HPLC-DAD-ESI-MS

\section{НРLC-DAD-ESI/MS МОНИТОРИНГ НА СТИЛБЕНИ ВО ЦРВЕНИ ВИНА ОД СОРТАТА ВРАНЕЦ ПРОИЗВЕДЕНИ СО ТРАДИЦИОНАЛНИ И СОВРЕМЕНИ МЕТОДИ НА ФЕРМЕНТАЦИЈА}

Во ова истражување е извршена квантификација на стилбени во вина од сортата Вранец (берба 2008 и 2009 год.) произведени со традиционални и современи методи на ферментација, во присуство на различни енолошки додатоци (ензим, дабов чипс и гроздови танини). Стилбените trans-ресвератрол и trans-ресвератрол-3-глукозид беа определени со примена на високоефикасна течна хроматографија (HPLC) поврзана со детектор со низа од диоди (DAD) и електроспреј масен детектор (ESI-MS). Содржината на trans-ресвератрол се движеше од 0,09 до 3,3 mg/l, додека на trans-ресвератрол-3-глукозид во границите од 1,13 до 2,6 mg/l. Беше забележано дека годината на берба, видот на ферментационите тенкови и енолошките додатоци имаат влијание на содржината на стилбени во вината. Вината произведени во 2008 година имаат повисока содржина на стилбени (средна вредност $1,89 \mathrm{mg} / \mathrm{l}$ ) во споредба со вината произведени во 2009 година (средна вредност 1,59 mg/l), најверојатно поради разлики во температурата и влажноста на воздухот во двете години. Со примена на современи тенкови за ферментација (Сифа и Ганимеде), проследено со додавање ензим, дабов чипс и гроздови танини, се произведуваат вина со повисока содржина на 
стилбени. Со примена на карактеристична векторска анализа е забележано групирање на вината според применетиот метод на ферментација.

Клучни зборови: стилбени; ферментаицја; енолошки додатоци; Вранец; HPLC-DAD-ESI-MS

\section{INTRODUCTION}

Polyphenols are important components present in grapes and wines, which determine their sensorial (mouthfeel, astringency and bitterness) and colour characteristics. Phenolic compounds are classified as flavonoids, including anthocyanins, flavan-3-ols, flavonols and dihydroflavonols, and non-flavonoids: hydroxybenzoic acids and derivatives, hydroxycinnamic acids and derivatives, and stilbenes [1,2]. Stilbenes are considered as phytoalexins present in grapes and wines. Their formation in grapes is mainly correlated to disease resistance [3-5]. In fact, they are biosynthesized by the grapevines as a defence response to stress, such as microbial infection and UV irradiation. The major source of stilbenes, which are mainly present in a glucosylated form, are grape skins [6]. Furthermore, stilbenes could be present in a lower amount in the grape seeds, as well as in the grape stems in a considerable amount [6-8].

One of the most relevant and extensively studied stilbenes is trans-resveratrol (3,5,4'trihydroxystilbene). In nature, resveratrol exists in two isomeric forms (cis- and trans-configurations), in free as well as in $\beta$-glucoconjugated forms. The 3-O- $\beta$-D-glucosides of cis- and trans-resveratrol are called piceids.

The concentration of stilbenes in wine depends mainly on the grape variety and their content in the grapes, but also depends on the winemaking technologies and aging conditions. However, within the same variety, significant differences in the resveratrol content can be found from one vintage to another [9-11]. Furthermore, climate, humidity, fungal diseases, soil and sanitary stage may modify the concentration of resveratrol and its derivatives in the grape at the moment of harvest, and thus their content in the final wine [12]. During the winemaking process, stilbenes are transferred from the grapes into the wine in low quantities [6]. The influence of temperature, $\mathrm{SO}_{2}$, yeast, enzymes, maceration, malolactic fermentation, and pre- and post-fermentative factors influencing the stilbene levels in wines have been studied [7, 13-18]. Thus, increased levels of resveratrol have been found after malolactic fermentation as a result of the glycoside cleavage of piceid. Moreover, different types of yeast can influence enzymatic hydrolysis, producing higher levels of resveratrol in wine [19]. The addition of commercial pectolytic enzymes to the pomace can increase the levels of stilbenes as well as other phenols [10, 20].

Stilbenes, and among them trans-resveratrol, have been suggested as one of the compounds in red wines possessing beneficial effects to human health, such as cardioprotective, neuroprotective and antileukemic effects [21, 22]. Moreover, it has been shown that trans-resveratrol inhibits the proliferation of tumour cells and has a cancer-chemopreventive potential [23].

The main objectives of this study were to examine the content of resveratrol and piceid in Vranac wines, the autochthonous and most important grape variety in Montenegro, accounting for about $80 \%$ of the total grapes in the country [24-26] and to study the influence of different vinification alternatives (enzyme, oak chips and grape tannins) on the content of stilbenes in the wines produced with traditional and modern methods. For that purpose, a high-performance liquid chromatography (HPLC) coupled to a diode array detector (DAD) and electrospray mass spectrometer (ESI-MS) was used to identify and quantify the stilbenes in wines.

\section{MATERIALS AND METHODS}

\subsection{Chemicals and reagents}

Commercial standards of trans-resveratrol and trans-piceid (trans-reservatrol-3-mono- $D$-glucoside) (purity $>99.9 \%$ ) were obtained from Sigma-Aldrich (Steinheim, Germany). Distilled water, acetonitrile, methanol, ethanol and glacial acetic acid were purchased from Merck, Germany. All solvents used were HPLC grade.

\subsection{Grapes}

Grapes from the autochthonous Montenegrin variety Vranac were used for wine production in two successive years: 2008 and 2009. Grapes were harvested from the vineyards of the company 13 . Jul - Plantaže, located at Cemovsko field, Montenegro. This field belongs to the sub-region of Podgorica, which is part of the Montenegrin Basin of Lake Skadar, whose geographical location is be- 
tween $41^{\circ} 50^{\prime}$ and $42^{\circ} 45^{\prime}$ north latitude and $16^{\circ}$ and $17^{\circ}$ east longitude. Vranac grapes were harvested at technological maturity: 22-24 ${ }^{\circ}$ Brix (levels between 20 and $24{ }^{\circ}$ Brix are desirable as objective criteria for estimating optimal grape maturity) in both studied years (2008 and 2009). In both years, the phytosanitary status of the grapes, determined visually, was satisfactory before harvest. The vine plants were planted in the year 1981, and the number of vines per hectare was $4807(2.6 \times 0.8 \mathrm{~m})$.

\subsection{Winemaking}

Winemaking was performed in the experimental winery for microvinification, 13. Jul Plantaže, Montenegro, in the period between $2^{\text {nd }}$ and $21^{\text {st }}$ of September, 2008 and 2009. After the grape crushing, the stems were removed and the pomace was placed into three fermentation tanks, vessel (capacity 100 liters), Sifa (capacity 3001 liters) and Ganimede (capacity 300 liters), in order to study the influence of traditional (using vessel) and modern fermentation methods (using Sifa and Ganimede tanks). In all 3 tanks (C-control wine (in the vessel), S-Sifa and G-Ganimede), the pomace was treated with potassium metabisulphite ( 5 $\mathrm{g} / 100$ liters) in order to suppress the polyphenol oxidase enzymes and wild yeast activity, followed by inoculation with commercial yeast (BDX yeast, Saccharomyces cerevisiae), provided by Lallemand (France). The yeast was prepared by rehydration $(20 \mathrm{~g} / 100$ liters $)$ in water $\left(30^{\circ} \mathrm{C}\right)$ and applied to the must for fermentation.

In order to study the influence of enological additions on the stilbenes extraction, wine from all three tanks (C, S and G) was separated to four additional lots in which enzyme, oak chips and grape tannins were added as follows: (1) wine without additions (TM-traditional maceration or control), (2) wine with the addition of enzyme (ENZ - enzymatic maceration), (3) wine with the addition of enzyme and oak chips (ENZ-OC - enzymatic maceration in the presence of oak chips), and (4) wine with the addition of enzyme, oak chips and grape tannins (ENZ-OC-GT - enzymatic maceration in the presence of oak chips and grape tannins). Enzyme (Lallzyme EX-V, provided by Lallemand, France) was added to all wines in the amount of 2 $\mathrm{g} / \mathrm{hl}$, the dose of oak chips was $100 \mathrm{~g} / \mathrm{hl}$ (French oak chips, Pronektar) and the dose of tannins was $20 \mathrm{~g} / \mathrm{hl}$, produced by non-fermented grape seeds provided by AEB (Italy). Wines were produced in two consecutive years (2008 and 2009), applying the same winemaking procedures and, in total, 12 lots were obtained for each year, or 24 lots for both years of production (2008 and 2009).

Maceration and fermentation was carried out for 8 days. During the fermentation, the pomace in the vessels was mechanically "pumped over" twice a day. In the Sifa and Ganimede tanks, after the second day of maceration, the pomace was "pumped over" four times a day, for a 48 hour period, and then six times a day until the end of fermentation. The temperature of fermentation ranged from 23 to $30{ }^{\circ} \mathrm{C}$. The wines were stabilized, at $-4^{\circ} \mathrm{C}$ for a period of 6-8 days, for tartrate stabilization and bottled. Bottled wines were stored at $10-15^{\circ} \mathrm{C}$ in a cellar and analysed ten months after bottling.

\subsection{Meteorological data processing}

The average seasonal and monthly temperatures $\left({ }^{\circ} \mathrm{C}\right)$, rainfalls $\left(1 / \mathrm{m}^{2}\right)$ and relative humidity (\%) were noted during the years 2008 and 2009, and results are presented in Table 1. All hydrometeorological data were obtained from the Hydrometeorological Institute of Montenegro (Podgorica). Monitoring, recording and collection of the data have been carried out by hydrometeorological stations, MONSTAT 2009 and 2010 [27, 28].

\section{Table 1}

Meteorological data measured during the ripening period in the experimental vineyards in 2008 and 2009

\begin{tabular}{ccccccc}
\hline \hline \multirow{2}{*}{ Year/Period } & \multicolumn{2}{c}{ Average temperature $\left({ }^{\mathbf{0}} \mathbf{C}\right)$} & \multicolumn{2}{c}{$\begin{array}{c}\text { Rainfall } \\
\left(\mathbf{1} / \mathbf{m}^{\mathbf{2}}\right)\end{array}$} & \multicolumn{2}{c}{$\begin{array}{c}\text { Relative humidity } \\
(\boldsymbol{\%})\end{array}$} \\
\cline { 2 - 7 } & Seasonal $^{\mathrm{a}}$ & Monthly $^{\mathrm{b}}$ & Seasonal $^{\mathrm{a}}$ & Monthly $^{\mathrm{b}}$ & Seasonal $^{\mathrm{a}}$ & Monthly $^{\mathrm{b}}$ \\
\hline 2008 & 23.1 & 25.8 & 66.8 & 39.8 & 53.2 & 45.3 \\
2009 & 23.6 & 26.4 & 65.5 & 31.0 & 55.2 & 51.0 \\
\hline \hline
\end{tabular}

aFrom 1st of April to 30th of September.

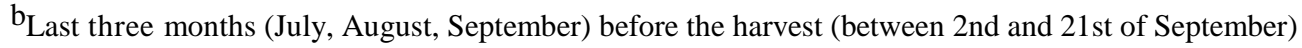




\subsection{HPLC-DAD-ESI/MS analysis of stilbenes}

An Agilent 1100 HPLC system was used for analysis of stilbenes in wines, equipped with an $\mathrm{Ag}$ ilent 1100 series DAD (G1315B), a G1312A binary pump, a G1329A autosampler, a G1379B degasser, a G1316A thermostat column and an Ion Trap Mass Detector in series (Agilent Technologies, Waldbronn, Germany). An Agilent ChemStation (version v.01.03) was used for data processing. Separation of compounds was performed with the Discovery Analytical C18 column from Supelco $(4.6 \mathrm{~mm} \times 150$ $\mathrm{mm}, 5 \mu \mathrm{m}$ ), using the following mobile phase: solvent $\mathrm{A}$, formic acid in water $(1 \% \mathrm{~V} / \mathrm{V})$ and solvent $\mathrm{B}$, acetonitrile, at a flow rate of $0.5 \mathrm{ml} / \mathrm{min}$. A linear gradient started with $15 \% \mathrm{~B}$, followed by $20 \% \mathrm{~B}$ at 5 to $15 \mathrm{~min}, 28 \% \mathrm{~B}$ at $30 \mathrm{~min}, 42 \% \mathrm{~B}$ at $50 \mathrm{~min}$ and $100 \% \mathrm{~B}$ at 55 to $65 \mathrm{~min}$. The temperature of the column was set on $40^{\circ} \mathrm{C}$ and the injection volume was $10 \mu \mathrm{l}$. The samples were filtered using $0.45 \mu \mathrm{m}$ cellulose membrane (Millipore, Bedford, USA) before direct injection into the HPLC system, kept at $25^{\circ} \mathrm{C}$.

Spectral data from all peaks were accumulated in the range of 190-600 $\mathrm{nm}$ and the chromatograms were recorded at $306 \mathrm{~nm}$ for the trans forms and $287 \mathrm{~nm}$ for the cis forms of piceid and resveratrol. Standard solutions of trans-resveratrol and trans-resveratrol-3-glucoside, used for construction of calibration curves, both in the range of 0.5 to $29.0 \mathrm{mg} / \mathrm{l}$, were prepared in methanol and kept in the dark at $5{ }^{\circ} \mathrm{C}$.

The Ion Trap Mass Spectrometer (MS) was equipped with an electrospray ionization (ESI) system and controlled by LCMSD software (Agilent, v.6.2). Nitrogen was used as the nebulizing gas at pressure of $50 \mathrm{psi}$, and the flow rate was adjusted to $12 \mathrm{l} / \mathrm{min}$. The temperature and the voltage of the capillary were maintained at $325{ }^{\circ} \mathrm{C}$ and $3.5 \mathrm{kV}$, respectively. MS data were acquired in the negative ionization mode. The full scan covered the mass range from $m / z, 100-450$. Collision - induced fragmentation experiments were performed in the ion trap using helium as collision gas with a voltage ramping cycle from 0.3 up to $2 \mathrm{~V}$. Maximum accumulation times of the ion trap and the number of MS repetitions to obtain the MS average spectra were set at $200 \mathrm{~ms}$ and 5, respectively.

\subsection{Statistical analysis}

Statistical treatments, including calculation of means and standard deviations, ANOVA and Principal Component Analysis (PCA), were per- formed on the data for trans-resveratrol and transresveratrol-3-glucoside. Fisher's honest significant difference (HSD) test $(p<0.05)$ was used to ascertain significant differences between the wines. PCA was carried out to explore clustering among the wines produced by different vinification methods and treatments. Statistical analyses were performed using the software STATISTICA 6.0 (StatSoft Inc., USA).

\section{RESULTS AND DISCUSSION}

\subsection{Identification of stilbenes in Vranac wines}

The HPLC-DAD-ESI/MS technique was used to identify and quantify the stilbenes in Vranac wines produced in two different vintage years (2008 and 2009), using different fermentation tanks (vessel, Sifa and Ganimede) and applying different enological additives (enzyme, oak chips and grape tannins). The assignment of the individual stilbenes was performed by comparison of their UV/Vis spectra (Figure 1) and retention times with the available standards, as well as by comparing the ESI/MS and MS/MS data with the standards analysed under the same experimental conditions and those found in the literature [11]. The UV/Vis chromatogram of one Vranac wine and standard solution, recorded at $306 \mathrm{~nm}$, is presented in Figure 2.

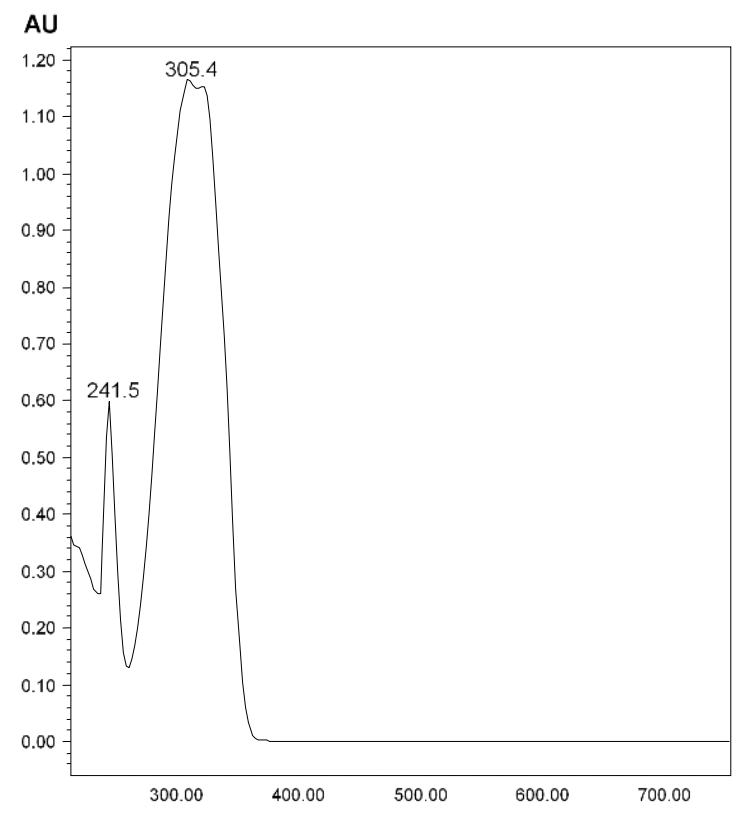

Fig. 1. UV/Vis spectra of resveratrol-glycoside recorded at 200 to $750 \mathrm{~nm}$ 


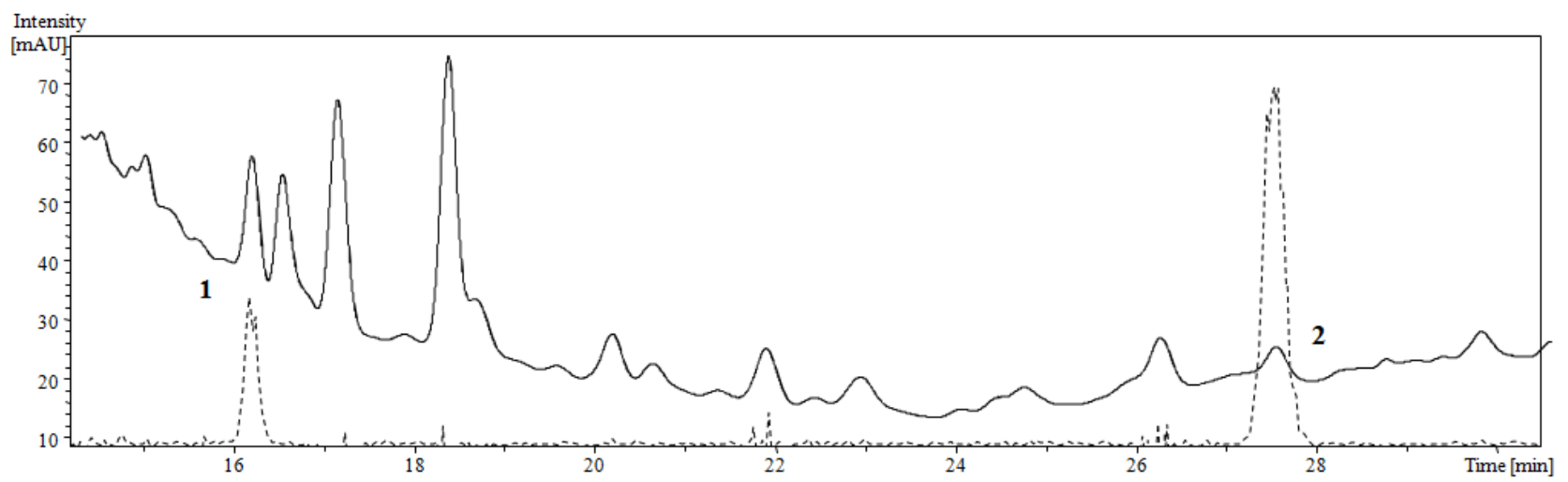

Fig. 2. UV/Vis chromatograms of Vranac wine (-) and standard solution (---) recorded at $306 \mathrm{~nm}$ for separation and quantification of stilbenes. Peak assignment: (1) trans-resveratrol-3-glucoside, $t_{\mathrm{R}}=16.2 \mathrm{~min}$; (2) trans-resveratrol, $t_{\mathrm{R}}=27.5 \mathrm{~min}$

Cis- and trans-resveratrol, and cis- and trans-resveratrol-3-glucosides (cis- and transpiceids) were detected in the wines by ESI/MS, giving pseudomolecular ions at $\mathrm{m} / \mathrm{z} 227$ and $\mathrm{m} / \mathrm{z}$ 389 , respectively. The pseudo-molecular ion of cis/trans-resveratrol glucoside (trans/cis-piceid) $[\mathrm{MH}]^{-}$at $m / z 389$ produced a fragment ion $[\mathrm{MH}]^{-}$ at $m / z 227$ corresponding to free resveratrol by loss of the glucose moiety ( $-162 \mathrm{Da})$ [29]. MS spectra of both stilbenes are shown in Figure 3.

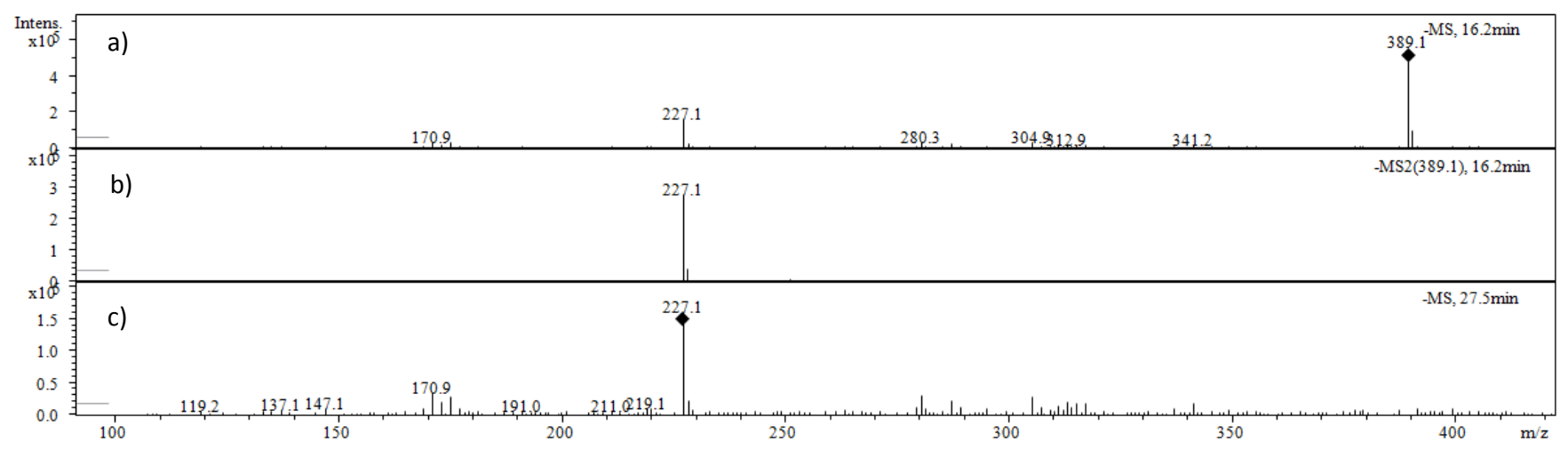

Fig. 3. MS/MS spectra of trans-resveratrol-3-glucoside (a, b) and trans-resveratrol (c) obtained in negative ion mode

\subsection{Quantitative analysis of stilbenes}

Quantification of stilbenes in the Vranac wines was performed using the peak areas in the HPLC-DAD chromatograms recorded at $306 \mathrm{~nm}$. Trans-resveratrol and its glucoside were quantified, while cis-isomers were not determined since they were found below the limit of quantification $(\mathrm{LOQ}=0.5 \mathrm{mg} / \mathrm{l})$. The applied method presented satisfactory linearity, with correlation coefficients of 0.9993 for trans-resveratrol and 0.9994 for trans-resveratrol-3-glucoside.

For all wines, trans-resveratrol ranged from 0.09 to $3.30 \mathrm{mg} / \mathrm{l}$ (average value: $1.73 \mathrm{mg} / \mathrm{l}$ ) (Table 2). These values were comparable with previously published results for Montenegrin, Macedonian, Serbian, Italian and Brazilian wines [3, 30-34]. In addition, the content of trans-resveratrol-3glucoside was in the range of 1.13 to $2.60 \mathrm{mg} / \mathrm{l}$ (average value: $1.72 \mathrm{mg} / \mathrm{l}$ ) and compared to the results from the literature [30-34]. Montenegrin Vranac wines contained a lower content of this stilbene, but similar levels with the red wines from Japan (0.17 to $3.54 \mathrm{mg} / \mathrm{l})$ and USA (nd- $0.59 \mathrm{mg} / \mathrm{l})$ [35].

Influence of vintage. In general, wines produced in vintage 2008 presented higher average amounts of stilbenes compared to the wines from the 2009 vintage. The average values of transresveratrol in wines produced in vintage 2008 and 2009 were 1.99 and $1.47 \mathrm{mg} / \mathrm{l}$, respectively, while the average values of trans-resveratrol-3-glucoside were 1.87 and 1.57 , respectively. 
Table 2

Stilbenes content ( $m g / l)$ in Vranac wines quantified with HPLC-DAD analysis

\begin{tabular}{|c|c|c|c|}
\hline Vinification alternative & Wines & $\begin{array}{c}\text { trans- resveratrol } \\
(\mathrm{mg} / \mathrm{l})\end{array}$ & $\begin{array}{c}\text { trans- resveratrol-3- } \\
\text { glucoside }(\mathrm{mg} / \mathrm{l})\end{array}$ \\
\hline \multicolumn{4}{|c|}{2008} \\
\hline TM & C1-08 & $0.29 \pm 0.02$ & $1.70 \pm 0.02$ \\
\hline ENZ & C2-08 & $0.30 \pm 0.02$ & $1.74 \pm 0.02$ \\
\hline ENZ-OC & C3-08 & $0.32 \pm 0.03$ & $1.68 \pm 0.01$ \\
\hline \multirow[t]{2}{*}{ ENZ-OC-GT } & $\mathrm{C} 4-08$ & $0.34 \pm 0.03$ & $1.69 \pm 0.01$ \\
\hline & Average & $0.31^{a}$ & $1.70^{a}$ \\
\hline $\mathrm{TM}$ & S1-08 & $2.44 \pm 0.05$ & $1.58 \pm 0.02$ \\
\hline ENZ & $\mathrm{S} 2-08$ & $2.68 \pm 0.07$ & $1.90 \pm 0.03$ \\
\hline ENZ-OC & S3-08 & $3.15 \pm 0.11$ & $2.02 \pm 0.05$ \\
\hline \multirow[t]{2}{*}{ ENZ-OC-GT } & S4-08 & $3.30 \pm 0.12$ & $1.84 \pm 0.03$ \\
\hline & Average & $2.89^{b}$ & $1.83^{b}$ \\
\hline $\mathrm{TM}$ & G1-08 & $2.66 \pm 0.07$ & $1.68 \pm 0.03$ \\
\hline ENZ & G2-08 & $3.02 \pm 0.09$ & $2.60 \pm 0.05$ \\
\hline ENZ-OC & G3-08 & $2.35 \pm 0.05$ & $1.60 \pm 0.03$ \\
\hline \multirow[t]{2}{*}{ ENZ-OC-GT } & G4-08 & $2.98 \pm 0.05$ & $2.38 \pm 0.04$ \\
\hline & Average & $2.75^{c}$ & $2.07^{c}$ \\
\hline \multicolumn{4}{|c|}{2009} \\
\hline TM & C1-09 & $0.09 \pm 0.01$ & $1.19 \pm 0.03$ \\
\hline ENZ & C2-09 & $0.10 \pm 0.01$ & $1.20 \pm 0.01$ \\
\hline ENZ-OC & C3-09 & $0.15 \pm 0.02$ & $1.13 \pm 0.02$ \\
\hline \multirow[t]{2}{*}{ ENZ-OC-GT } & C4-09 & $0.15 \pm 0.02$ & $1.14 \pm 0.02$ \\
\hline & Average & $0.13^{a}$ & $1.17^{a}$ \\
\hline $\mathrm{TM}$ & S1-09 & $1.85 \pm 0.05$ & $1.40 \pm 0.00$ \\
\hline ENZ & S2-09 & $2.08 \pm 0.05$ & $1.73 \pm 0.01$ \\
\hline ENZ-OC & S3-09 & $2.85 \pm 0.12$ & $1.85 \pm 0.01$ \\
\hline \multirow[t]{2}{*}{ ENZ-OC-GT } & S4-09 & $3.10 \pm 0.11$ & $1.67 \pm 0.02$ \\
\hline & Average & $2.47^{b}$ & $1.66^{b}$ \\
\hline $\mathrm{TM}$ & G1-09 & $1.14 \pm 0.07$ & $1.56 \pm 0.02$ \\
\hline ENZ & G2-09 & $2.27 \pm 0.03$ & $2.46 \pm 0.02$ \\
\hline ENZ-OC & G3-09 & $1.61 \pm 0.09$ & $1.47 \pm 0.03$ \\
\hline \multirow[t]{2}{*}{ ENZ-OC-GT } & G4-09 & $2.21 \pm 0.01$ & $2.22 \pm 0.08$ \\
\hline & Average & $1.81^{c}$ & $1.93^{c}$ \\
\hline
\end{tabular}

Abbreviations: TM - traditional maceration, ENZ - enzymatic maceration, ENZ - OC-enzymatic maceration in presence of oak chips, ENZ-OC-GT - enzymatic maceration in presence of oak chips and grape tannins $\mathrm{C}-$ Control wines

$\mathrm{S}$ - Sifa method (Sifa fermentation tank)

$\mathrm{G}-$ Ganimede method (Ganimede fermentation tank)

$08-2008$ vintage, 09 - 2009 vintage

ANOVA was used to compare data (n.s. not significant, a,b,c, $p \leq 0.05$ ). Different lower-case letters indicate significant differences between winemaking procedures using Fisher's HSD test $(p \leq 0.05)$.

In fact, it is known that climate and weather conditions influence the stilbenes content in grapes. Thus, the average temperature in 2008, during the three months before the grape harvest was lower $\left(25.8^{\circ} \mathrm{C}\right)$ compared to the same period in $2009\left(26.4{ }^{\circ} \mathrm{C}\right)$ (Table 1). Moreover, there was more rainfall in $2008\left(39.8 \mathrm{l} / \mathrm{m}^{2}\right)$ compared to 2009 $\left(31.0 \mathrm{l} / \mathrm{m}^{2}\right)$, and the relative humidity (R.H.) was lower in $2008(45.3 \%)$ than in 2009 (51 \%) (Table
1). In such humid climatic conditions (especially during the summer period) grape berries are commonly attacked by Botrytis cinerea which can act as an elicitor toward the production of transresveratrol in grapevines, resulting in higher amounts of this stilbene in grapes, and then, higher amount in the wines. Thus, the weather and climate conditions could be the reason for the differences in stilbene levels in the wines produced in the two 
vintage years. Our findings were in agreement with the results from previous research studies indicating that weather conditions influence the content of stilbenes in wine [12, 35, 36].

Influence of fermentation tanks. With regard to the influence of fermentation tanks used for wine production, it was found that modern vinification methods influenced significantly higher content $(p>0.05)$ of stilbenes, especially evident in trans-resveratrol (average values: $2.49 \mathrm{mg} / \mathrm{l}$ trans-resveratrol and $1.87 \mathrm{mg} / \mathrm{l}$ trans-resveratrol-3glucoside), compared to the traditional/classical production method (average values: $0.22 \mathrm{mg} / \mathrm{l}$ trans-resveratrol and $1.43 \mathrm{mg} / \mathrm{l}$ trans-resveratrol-3glucoside). Thus, trans-resveratrol in the wines produced in Sifa and Ganimede tanks ranged from 1.85 to $3.30 \mathrm{mg} / \mathrm{l}$ and 1.14 to $3.02 \mathrm{mg} / \mathrm{l}$, respectively, while in the vessels its content was significantly lower $(p<0.05)$ (range: 0.10 to $0.34 \mathrm{mg} / \mathrm{l})$. Similarly, the content of trans-resveratrol-3-glucoside in the wines produced by the traditional method was slightly lower $(p>0.05)$ (range: 1.13 to 1.74 $\mathrm{mg} / \mathrm{l}$ ) compared to the wines produced in Sifa and Ganimede tanks (range: 1.40 to $2.02 \mathrm{mg} / \mathrm{l}$ and 1.47 to $2.60 \mathrm{mg} / \mathrm{l}$, respectively). In fact, it is know that winemaking technology and maceration time significantly influence the extraction of stilbenes from grapes into the wine, which is more efficient at the latest stages of the winemaking when the content of ethanol is sufficient to dissolve them and significantly higher from the beginning of fermentation [32]. Moreover, the watertight tanks Ganimede and Sifa, which are hermetically closed, prevent oxidation of the wine and allow efficient and selective extraction of polyphenols, and thus, stilbenes too. In these tanks, strong mechanical action is not required, and thus prevents aggressive action on the cap. All the energy needed originates from the natural $\mathrm{CO}_{2}$ produced during the fermentation process, allowing re-stirring cycles/délestage without the use of pumps, influencing the higher extraction of stilbenes from the grapes, as was observed in our study. These results are in accordance with results for stilbenes in wines published in previous studies [37, 38].

In addition, it was evident that the content of trans-resveratrol in wines produced with the Sifa and Ganimede methods was higher compared to resveratrol-3-glucoside. The most likely reason is the enzymatic cleavage of trans-piceid during the winemaking process in the closed and modern tanks $[19,32]$ producing the free aglycon form and increasing its content in the wine.

Influence of enological additions. The highest concentration of trans-resveratrol was meas- ured in the ENZ-OC-GT wines (the wines containing enzyme, oak chips and grape tannins). This was evident in the control (C) and Sifa (S) wines, produced in both years, 2008 and 2009 (C4-08: $0.34 \mathrm{mg} / \mathrm{l}$ and C4-09: $0.15 \mathrm{mg} / \mathrm{l}$, respectively, and S4-08: $3.30 \mathrm{mg} / 1$ and $\mathrm{S} 4-09: 3.10 \mathrm{mg} / \mathrm{l}$, respectively), as well as in Ganimede wine from vintage 2008 (G4-08: $2.98 \mathrm{mg} / \mathrm{l}$ ). Ganimede wines from the 2009 vintage presented the highest resveratrol content in the ENZ wine (G2-09: $2.27 \mathrm{mg} / \mathrm{l})$, followed by the ENZ-OC-GT wine (G4-09: 2.21 $\mathrm{mg} / \mathrm{l})$. Because stilbenes are mainly located in the grape skins, our results suggest that macerating enzyme increases the stilbene's extraction from skins, but the addition of oak chips, as well as grape seed tannins cannot be expected to influence directly on their levels because stilbenes are not grape seed compounds. Most likely, the highest content of stilbenes in ENZ-OC-GT wines is a consequence of the oxidative protection of must and wine by the addition of oak chips and tannins, allowing higher extraction of skin compounds, with stilbenes among them. The reason could also be due to the commercial formulation including material from origin other than grape seeds (such as grape skins) that could also increase the level of resveratrol [39].

With regard to the content of piceid, differences were observed between the wines. The highest amount in the control wines (C) was found in ENZ wines from both years (C2-08: $1.74 \mathrm{mg} / \mathrm{l}$ and C1-08: $1.70 \mathrm{mg} / \mathrm{l}$, respectively). ENZ-OC wines produced with the Sifa method (S2-08:1.90 mg/l and S3-08: $2.02 \mathrm{mg} / \mathrm{l}$ ) presented the highest amount of piceid, and for Ganimede wines, the highest levels were found in G2-2008 (ENZ) and G2-2009 (ENZ) wines.

\subsection{Principal component analysis (PCA)}

PCA was applied on the results for resveratrol and resveratrol-3-glucoside, and used to explore the contribution of each parameter (vintage, fermentation tanks, addition of enzyme, oak chips and grape tannins) on the clustering among the wines, without axes rotation. In addition, the Bartlett's test of sphericity was performed, which is the test for null hypothesis that the correlation matrix has an identity matrix. This test provides the minimum standard to proceed for PCA and confirmed that the correlation between the variables was significant $(p<0.05)$.

The first two principal components, $\mathrm{PC} 1$ and PC2, accounted for $100.0 \%$ of the total variance (82.84\% for PC1 and $17.16 \%$ for PC2). The pro- 
jection of the Vranac wine samples on the first two principal components showed a clear separation according to the method used for fermentation (Fig. 4). Thus, wines fermented with the traditional method were clearly separated from the wines produced with the Sifa and Ganimede methods and located in the negative part of PC1. Moreover, control wines were subsequent grouped according to the vintage: wines produced in 2008 were clearly separated from the wines produced in 2009 as a result of the difference in the stilbenes content (wines from 2008 presented higher levels of stilbenes). Among the wines produced with the modern methods, G4-2008, G4-2009 and G2-2009 wines were separated according to the higher content of trans-resveratrol-3-glucoside and located in the lower part of PC1. All other wines located in the upper part of $\mathrm{PC} 1$ were characterized with higher levels of trans-resveratrol.

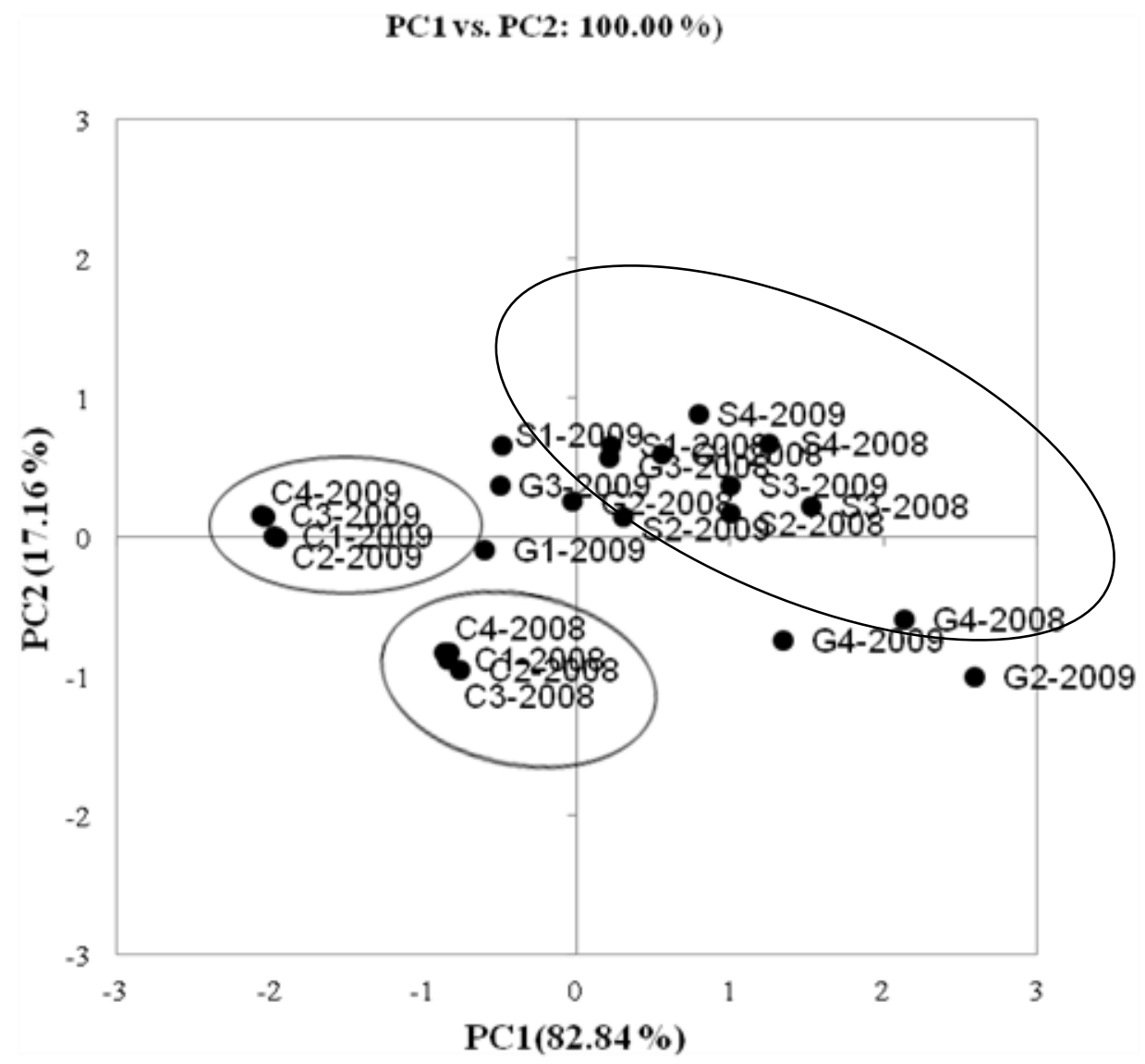

Fig. 4. Classification of Vranac wines produced with different fermentation tanks (classical, Sifa and Ganimede) during 2008 and 2009 and applying different enological additives (enzyme, oak chips and grape tannins) analysed in function of PC1 and PC2, based on resveratrol and resveratrol-3-glucoside variables. Labels of the wines correspond to those in Table 2.

\section{CONCLUSIONS}

Vranac grapes are autochthonous and the most important red variety in Montenegro. In this study, quantitative analysis of stilbenes was performed on Vranac wine, which was found to have very rich stilbene levels. Moreover, results showed that vintage, fermentation methods, and additions of enzyme, oak chips and grape tannins improved the stilbenes levels, enhancing their extraction in the wines, meaning that vinification can be planed, controlled and modified in order to obtained wines with high content of antioxidants, such as stilbenes.

\section{REFERENCES}

[1] D. O. Adams, Phenolics and ripening in grape berries, Am. J. Enol. Vitic. 57, 249-256 (2006).

[2] V. Ivanova-Petropulos, I. Hermosín-Gutiérrez, B. Boros, M. Stefova, T. Stafilov, B. Vojnoski, Á. Dörnyei, F. Kilár, Phenolic compounds and antioxidant activity of Macedonian red wines, J. Food. Comp. Anal. 41, 1-14 (2015). DOI:10.1016/j.jfca.2015.01.002. 
[3] M. Atanacković, A. Petrović, S. Jović, L. GojkovićBukarica, M. Bursac, J. Cvejic, Influence of winemaking techniques on the resveratrol content, total phenolic content and antioxidant potential of red wines, Food Chem. 131, 513-518 (2012).

DOI:10.1016/j.foodchem.2011.09.015.

[4] P. Langcake, R. J. Pryce, The production of resveratrol by Vitis vinifera and other members of the Vitaceae as a response to infection or injury, Physiol. Plant Pathol. 9, 77-86 (1976).

[5] P. Langcake, Disease resistance of Vitis spp. and the production of the stress metabolites resveratrol, $\varepsilon$ viniferin, $\alpha$-viniferin and pterostilbene, Physiol. Plant Pathol. 18, 213-226 (1981).

[6] B. S. Sun, A. M. Ribes, M. C. Leandro, A. P. Belchior, M. I. Spranger, Stilbenes: quantitative extraction from grape skins, contribution of grape solids to wine and variation during wine maturation, Anal. Chim. Acta, 563, 382-390 (2006). DOI:10.1016/j.aca.2005.12.002.

[7] R. Pezet, Ph. Cuenat, Resveratrol in wine: extraction from skin during fermentation and post-fermentation standing of must from Gamay grapes, Am. J. Enol. Vitic. 47, 287-290 (1996).

[8] L. Bavaresco, E. Cantu, M. Fregoni, M. Trevisan, Constitutive stilbene contents of grapevine cluster stems as potential source of resveratrol in wine, Vitis, 36(3), 115118 (1997)

[9] A. Roldán, V. Palacios, I. Caro, L. Pérez, Resveratrol content of palomino fino grapes: influence of vintage and fungal infection, J. Agric. Food Chem. 51, 14641468 (2003). DOI:10.1021/jf020774u.

[10] R. T. Threlfall, J. R. Morris, A. Mauromoustakos, Effect of variety, ultraviolet light exposure, and enological methods on the trans-resveratrol level of wine, Am. J. Enol. Vitic. 50 (1), 57-64 (1999).

[11] F. Mattivi, Solid-phase extraction of trans-resveratrol from wines for HPLC analysis, Z. Lebensm. Unters. Forsch. 196 (6), 522-525 (1993).

[12] D. M. Goldberg, J. Yan, E. Ng, E. P. Diamandis, A. Karumanchiri, G. Soleas, A. L. Waterhouse, A global survey of trans-resveratrol concentrations in comercial wines, Am. J. Enol. Vitic. 46, 159-165 (1995).

[13] V. Vacca, L. Leccis, P. Fenu, L. Pretti, G. A. Farris, Wine yeasts and resveratrol content, Biotech. Lett. 19, 497-498 (1997).

[14] U. Vrhovsek, S. Wendelin, R. Eder, Effects of various vinification techniques on the concentration of cis- and trans-resveratrol and resveratrol glucoside isomers in wine, Am. J. Enol. Vitic. 48, 214-219 (1997).

[15] A. Gambuti, D. Strollo, A. Erbaggio, L. Lecce, L. Moio, Effect of winemaking practices on color indexes and selected bioactive phenolics of Aglianico wine, J. Food Sci. 72(9), S623-S628. (2007). DOI:10.1111/j.1750-3841.2007.00536.x.

[16] G. González-Neves, G. Favre, G. Gil, M. Ferrer, D. Charamelo, Effect of cold pre-fermentative maceration on the color and composition of young red wines cv. Tannat., J. Food Sci. Tech. Mys. 52, 3449-3457 (2015). DOI:10.1007/s13197-014-1410-y.
[17] V. Ivanova, B. Vojnoski, M. Stefova, Effect of winemaking treatment and wine aging on phenolic content in Vranec wines, J. Food Sci. Technol. 49(2), 161-172 (2012). DOI: 10.1007/s13197-011-0279-2.

[18] V. Ivanova-Petropulos, S. Durakova, A. Ricci, G. P. Parpinello, A. Versari, Extraction and evaluation of natural occurring bioactive compounds and change in antioxidant activity during red winemaking, J. Food Sci. Technol. 53 (6), 2634-2643 (2016). DOI: $10.1007 / \mathrm{s} 13197-016-2235-7$.

[19] G. L. La Torre, G. Laganà, E. Bellocco, F. Vilasi, F. Salvo, G. Dugo, Improvement on enzymatic hydrolysis of resveratrol glucosides in wine, Food Chem. 85, 259266 (2004). DOI:10.1016/j.foodchem.2003.06.019.

[20] J. D. Wightman, S. F. Price, B. T. Watson, R. E. Wrolstad, Some effects of processing enzymes on anthocyanins and phenolics in Pinot noir and Cabernet Sauvignon wines, Am. J. Enol. Vitic. 48, 39-48 (1997).

[21] M. Urpi-Sarda, O. Jauregui, R. M. Lamuela-Raventos, W. Jaeger, M. Miksits, M. I. Covas, C. Andres-Lacueva, Uptake of diet resveratrol into the human low-density lipoprotein. Identification and quantification of resveratrol metabolites by liquid chromatography coupled with tandem mass spectrometry, Anal. Chem. 10, 3149-3155 (2005). DOI:10.1021/ac0484272.

[22] M. Virgili, A. Contestabile, Partial neuroprotection of in vivo excitotoxic brain damage by chronic administration of the red wine antioxidant agent, trans-resveratrol in rats, Neurosci. Lett. 281(2-3), 123-126 (2000).

[23] M. Jang, L. Cai, G. O. Udeani, K. V. Slowing, C. F. Thomas, C. W. Beecher, Cancer chemopreventive activity of resveratrol, a natural product derived from grapes, Science, 275, 218-220 (1997).

[24] R. Pajovic, D. Raicevic, T. Popovic, P. Sivilotti, K. Lisjak, A. Vanzo, Polyphenolic characterisation of Vranac, Kratosija and Cabernet Sauvignon (Vitis vinifera L. cv.) grapes and wines from different vineyard locations in Montenegro, S. Afr. J .Enol. Vitic. 35(1), 134-143 (2014).

[25] D. Raicevic, S. Mijovic, T. Popovic, R. PajovicScepanovic, Phenolic compounds of red wines in Podgorica subregion (Montenegro), Agricult. Forest. 61(4), 359-368 (2015). DOI:10.17707/AgricultForest.

[26] D. Raičević, Z. Božinović, M. Petkov, V. IvanovaPetropulos, V. Kodžulović, M. Mugosa., S. Sucur, V. Maras, Polyphenolic content and sensory profile of Montenegrin Vranac wines produced with different oenological products and maceration, Maced. J. Chem. Chem. Eng. 36(2), 229-238 (2017). DOI: $10.20450 /$ mjcce.2017.1145.

[27] MONSTAT-Statistical Office of Montenegro, Statistical Yearbook. MONSTAT, Podgorica (2009).

[28] MONSTAT-Statistical Office of Montenegro, Statistical Yearbook. MONSTAT, Podgorica (2010).

[29] V. Ivanova, Á. Dörnyei, L. Márk, B. Vojnoski, T. Stafilov, M. Stefova, F. Kilár, Polyphenolic content of Vranec wines produced by different vinification conditions, Food Chem. 124(1), 316-325 (2011). DOI:10.1016/j.foodchem.2010.06.039.

[30] R. Pajović Šćepanović, S. Wendelin, D. Raičević, E. Reinhard, Characterization of the phenolic profile of 
commercial Montenegrin red and white wines, Eur. Food Res. Techn. 245, 2233-2245 (2019), DOI: 10.1007/s00217-019-03330-z.

[31] R. Pajović-Šćepanović, S. Wendelin, E. Reinhard, Phenolic composition and varietal discrimination of Montenegrin red wines (Vitis vinifera var. Vranac, Kratošija, and Cabernet Sauvignon), Eur. Food Res. Techn. 244 (12), 2243-2254. (2018). DOI: $10.1007 / \mathrm{s} 00217-018-3133-1$.

[32] S. Kostadinovic, A. Wilkens, M. Stefova, V. Ivanova, B. Vojnoski, H. Mirhosseini, P. Winterhalter, Stilbene levels and antioxidant activity of Vranec and Merlot wines from Macedonia: Effect of variety and enological practices, Food Chem. 135, 3003-3009 (2012). DOI: 10.1016/j.foodchem.2012.06.118.

[33] F. Buiarelli, F. Coccioli, R. Jasionowska, M. Merolle, A. Terracciano, Analysis of some stilbenes in Italian wines by liquid chromatography/tandem mass spectrometry, Rapid Commun. Mass. Spectrom. 21, 2955-2964 (2007). DOI:10.1002/rcm.3174.

[34] X. Vitrac, A. Bornet, R. Vanderlinde, J. Valls, T. Richard, J. C. Delaunay, J. M. Mrillon, P. L. Teissdre, Determination of stilbenes (trans-viniferin, trans-astringin, trans-piceid, cis- and trans-resveratrol, cis-viniferin) in
Brazilian wines, J. Agric. Food Chem. 14, 5664-5669 (2005). DOI:10.1021/jf050122g.

[35] U. Stervbo, O. Vang, C. Bonnesen, A review of the content of the putative chemopreventive phytoalexin resveratrol in red wine, Food Chem. 101, 449-457 (2007). DOI:10.1016/j.foodchem.2006.01.047.

[36] L. Bavaresco, S.Pezzutto, F. Ferrari, Role of environmental and cultural factors on resveratrol content in grapes and wine, Italus Hortus, 74 (3), 191-194 (2007).

[37] T. Garde-Cerdán, I. Jarauta, S. M. Rosario, C. AncínAzpilicueta, Comparative study of the volatile composition in wines obtained from traditional vinification and from the Ganimede method, J. Sci. Food Agric. 88 (10), 1777-1785 (2008). DOI: 10.1002/jsfa.3280.

[38] E. S. Vázquez, S. R. Segade, I. O. Fernández, Effect of the winemaking technique on phenolic composition and chromatic characteristics in young red wines, Eur. Food Res. Techn. 231, 789-802. (2010). DOI: $10.1007 / \mathrm{s} 00217-010-1332-5$.

[39] G. Favre, Á. Peña-Neira, C. Baldi, N. Hernández, S. Traverso, G. Gil, G. González-Neves, Low molecularweight phenols in Tannat wines made by alternative winemaking procedures, Food Chem. 158, 504-512 (2014). DOI:10.1016/j.foodchem.2014.02.173. 